\title{
Practices of Fixed-Price Work : Trades, Techniques and Subcontracting in a Eurasian Perspective, Eighteenth to the Twentieth Century. An Introduction
}

\author{
Manuela Martini*, Liliane Hilaire-PÉrez**, Giorgio Riello***
}

$\mathrm{F}$ ar from being a form of production and labour organization inherent to the crisis that has shaken Western economies since the 1970s, subcontracting is a practice with a long history in different productive contexts. The purpose of this special issue is to explore subcontracting in economic sectors characterised by subcontracting systems. Some of these sectors have been the subject of close observation by contemporary economists, jurists, civil servants, and economic actors. This special issue therefore considers the historical role of

* Manuela MARTINI, born in 1962, is professor in modern history at University Lumière Lyon 2, member of the Laboratoire de recherche historique Rhône-Alpes (LARHRA-UMR 5190). She has recently published : Bâtiment en famille. Migration et petite entreprise en banlieue parisienne au XXe siècle (Paris, CNRS Éditions, 2016), and the edited book, with Raffaella Sarti and Anna Bellavitis, What is work? Gender at the Crossroads of Home, Family and Business from the Early Modern Era to the Present, Oxford-New York, Berghahn, 2018. Address: LARHRA-MSH Lyon Saint-Étienne, 14 avenue Berthelot, 69007 Lyon (manuela.martini@ univ-lyon2.fr).

** Liliane Hilaire PÉREz, born in 1960, is professor in early modern history at University of Paris, member of the laboratory Identités, Cultures, Territoires (ICT-EA 337) and senior research à l'EHESS, member of the Centre Alexandre Koyré. She has published her habilitation dissertation as La pièce et le geste. Artisans, marchands et savoirs techniques à Londres au XVIII e siècle (Paris, Albin Michel, 2013. She is the director of the journal ARTEFACT. Techniques, histoire et sciences humaines. Address: UFR GHES, Université Paris Diderot, 5, rue Thomas Mann 75205 CEDEX 13 Paris. Case courrier 7001 (liliane. perez@wanadoo.fr).

*** Giorgio Riello, born in 1974, is Chair of Early Modern Global History at the European University Institute in Florence, Italy, on leave from the University of Warwick, UK. He is the author of several books in the field of global history among which Cotton: The Fabric that Made the Modern World (CUP 2013; pb 2015 - recipient of the World History Association Book Prize 2014) and Luxury: A Rich History (OUP, 2016 - co-authored with Peter McNeil). Address: Department of History and Civilization, European University Institute, Via Bolognese 156, 50139 Florence, Italy (giorgio.riello@eui.eu). 
alternative forms of manufacturing in relation to factory concentration, focusing in particular on subcontracting relationships as part of craft and industrial organization.

Since the 1980s the theme of flexible specialization has been a central concern for historians working on the theme of 'historical alternatives to mass production.' Subcontracting and other flexible forms of organization of production are well-known topics in economic history and in the social sciences. ${ }^{2}$ In the past generation they have been researched either as ideal forms of industrial flexibility or, conversely, as negative forms of labour exploitation. In periods of crisis and the industrial reconfiguration of the 1970s, subcontracting was hailed as the solution to the rigidity of Taylorist and Fordist systems. At the same time, however, subcontracting has been seen as strongly linked to forms of exploitation of labour, be it sweated labour in nineteenth-century metropolises or in today's garment factories of Asia.

This special issue proposes a new view of such an important and long-lasting form of organization of production and labour. First, it highlights the need to compare in time and space different experiences of subcontracting and other forms of 'fragmentation of production' such as homework, piece-rate production, informal contracts among firms, family businesses, and self-employed individuals. Notwithstanding the wide range of forms that subcontracting assumes, we highlight the common features that this organizational form of production takes. Second, we underline the need to better understand the internal logics of subcontracting relationships and workshop organization; and in particular the role played by subcontractors. In empirical case studies we can observe a complex range of chain links in the sequence of sub-contracting. Although often victimized as exploited labour, the last subcontractors in the chain of production have likewise expressed agency. The internal logic of subcontracting shows that the distinction between employer and employee is fluid and depends on market, capital and entrepreneurial conditions. The articles included in this special issue therefore contribute to the debate on the juridical status of subcontractors, principals and subcontracting chains. ${ }^{3}$ We also emphasize the importance of contextualizing subcontracting in relation to consumers and distributors. Changes in consumption (such as the variety of products required by consumers and more recently customization)

1 Sabel, Zeitlin, 1997.

2 Salais, Storper, 1993.

3 Hilaire-PÉrez, 2013; Martini, 2016. 
have often entailed the practice of subcontracting as a way to respond swiftly and effectively to changing consumer choices. ${ }^{4}$

\section{THE GENESIS OF A CONCEPT}

Subcontracting is as difficult to define as it is to pinpoint historically. It refers to the services provided by a "sub-contractor" to a "buying firm" or "principal" for the production of pieces, components or subassemblies to be incorporated into a product that the principal will sell. ${ }^{5}$ As subcontracting relations have been omnipresent in both Western and non-Western manufacturing systems at least since the European middle ages, if not earlier, their study has been informed both by a variety of historical analyses as well as by theoretical approaches of several social science disciplines. Among them, one must cite the field of industrial economics and in particular the attention given since the 1960s to the role played by institutions in economic development. Business studies have also been important in understanding subcontracting especially through analyses of different typologies of organisation of production. Similarly subcontracting relations have been shaped by regulations on the rights of workers, subcontractors and principals mostly within the fields of commercial law and labour rights. In recent decades sociology and anthropology have opened new dimensions in the study of subcontracting by examining the daily life of workers, their social formations and their experience of work. ${ }^{6}$

Perhaps because of its polyvalence, subcontracting has found different contexts in economic, societal and cultural debates. It is worth highlighting three of them. First, economics has examined the question of a firm's boundaries, the limits of vertical integration and what constitutes the core activities of a firm. In particular the work by Ronald H. Coase carried out in the 1930s and the research by Oliver Williamson in the 1970s and 1980s on transaction-cost economics, provided a broad conceptualisation of the different varieties of firms determined by particular configurations of the costs incurred in searching, negotiating and monitoring transactions. ${ }^{7}$ This research was not specifically interested in assessing either the nature or advantages of subcontracting; it attempted instead to explain firms as a way of internalising transactions thus reducing the cost that otherwise an economic agent would have encountered

\footnotetext{
4 Riello, 2008; Perry, 1999.

5 Martini, 2015a. For a juridical definition, see: Valentin, 1979; Braudo, 2019.

6 Perraudin, Thèvenot, Tinel, Valentin, 2006.

7 Coase, 1937; Williamson, 1979 and 1985. See also Langlois, 2004.
} 
in approaching the market. A corollary to research on transaction costs has been the non-economic understanding of both firms, market based transactions and contractual relationships such as subcontracting. It has been noted, for instance, that in societies in which trust is part of a socially shared value system, and in which breaches are socially disapproved of, subcontracting functions smoothly. An example is Japan where subcontractors have a much weaker tendency toward litigation than for instance in the US. ${ }^{8}$

As already mentioned, subcontracting emerged as a concept in its own right (rather than as an exception to the internalisation of functions within firms) in the course of the 1970s and 1980s. Two changes should be mentioned: first a re-assessment of small businesses and second the search for more flexible industrial productive models. When in 1973 Ernst Schumacher first published his much acclaimed book Small is Beautiful, the existing paradigm was Chandlerian in nature and promoted the virtues of large-scale vertically integrated corporations. Schumacher opened new avenues of research on small businesses, claiming that these should not be seen as enterprises that failed in their search for expansion and growth or the remnant of 'traditional' and rather backward productive structures. By contrast, he claimed, small businesses could be cutting edge in innovation (a concept today fully subsumed into the concept of a 'start-up') and flexible in their organisation of production. ${ }^{9}$

This reassessment of small firms was also a critique of the industrial model of mass production, a manufacturing process for standard products built by highly specialised machinery and semi-skilled workers that had been pervasive in the organisation of production since at least the second industrial revolution. What was at stake in the late 1970s was a move beyond mass production, necessitating a redefinition of, and political positioning on, the technical and institutional choices required in the production of goods for increasingly segmented markets and for progressively more discerning consumers. The idea of linking crisis to the rigidity of the mass production system is common today, but at the beginning of the 1970s it had no place in either theory nor in the empirical work of business history. It took an unorthodox economist like Michael J. Piore and political scientists with deep knowledge of different European industrial landscapes such as Charles F. Sabel and Jonathan Zeitlin to conceive a model of flexible specialisation as an alternative to Fordism. ${ }^{10}$

8 Williamson, 1986; Thoburn, Takashima, 1992.

9 This famous expression derives from SCHUMACHER, 1973.

10 Some remarks on the origin of these fields of study can be found in MARTini, 2015a. 
This original research led to the publication of Piore and Sabel's The Second Industrial Divide (1984), Sabel and Zeitlin's influential 1985 article on 'alternatives to mass production' and their later collection of essays entitled Alternatives to Mass Production (1997). ${ }^{11}$ In contrast to the mass production model of the big vertically integrated firm, the model of flexible specialization has given rise to numerous studies of industrial districts and localised production systems. Suzanne Berger and Harry Katz, Giacomo Becattini, Michele Salvati, Sebastiano Brusco, Robert Boyer and Jean-Jacques Silvestre, as well as sociologists of industrial districts and local production systems such as Vittorio Capecchi, Carlo Trigilia, and Arnaldo Bagnasco were important voices in this debate in the 1990s.

What distinguished the debate over flexible specialisation and alternatives to mass production was its historical nature. By the early 1980s it was acknowledged that a process of economic 'modernisation' - rather than 'industrialisation' - included a wide variety of phenomena and could no longer be reliant on positivist assumptions of unilateral growth or development. The outcome has been the re-evaluation of the plurality of paths towards economic development and a more thorough consideration of urban productive systems especially in the eighteenth and nineteenth century. Here one should mention the work of Maxine Berg and Pat Hudson on manufactures or the historical understanding of industrial districts as for instance in a now large body of scholarship on Italy and France. ${ }^{2}$

Today subcontracting is no longer seen as linked to industrial alternatives to mass production and not even to a search for flexibility. Since the 1980s international subcontracting has garnered the attention of international organizations such as the OECD (Organization for Economic Co-operation and Development) and UNIDO (United Nations Industrial Development Organization). Alternative perspectives on these policies have emerged in the larger context of critiques of globalization. ${ }^{13}$ They have interpreted international subcontracting as a form of capitalist division of labour and exploitation by industrialized countries in relation to the World South. Themes such as sweatshops, homework and gender issues in specific sectors have been

11 Piore, Sabel, 1984; Sabel, Zeitlin, 1985; Sabel, Zeitlin, 1997. See also Fù̀, 1985.

12 Berg, Hudson, Sonenscher, 1983; Berg, 1985 and 1994. The literature on industrial districts is enormous in the case of Italy and is now becoming a topic of analysis also in Britain and France. See for instance: Popp, 2001; Wilson, Popp, 2003, especially introduction. For France see: DAumas, 2007; Eck, Lescure, 2002; GANne, 1989 and 1995. Martini, 2015b. 
transposed to the global level. ${ }^{14}$ More recently, this critical approach has manifested itself in forms of advocacy for sustainable global outsourcing. ${ }^{15}$

Global commodity chains and value chains reveal complex and far-fromlinear forms of subcontracting. These are most evident in the production of consumer goods, for instance the case of sport shoes or in the clothing industry in China. Gilles Guiheux shows that this is the case for large companies producing for Western clients who are aware of the entire sub-contracting production cycle as well as for chains of small and medium-sized companies producing low-end clothes in contemporary urban China for the domestic market or, occasionally, for foreign buyers. ${ }^{16}$

Subcontracting in the age of globalization includes forms of externalisation, offshoring, delocalization, partnering, and outsourcing. Indeed, today subcontracting is labelled differently depending on which economic actor, principal or subcontractor, or which dimension of their relationships is emphasized. Services are the new frontier of subcontracting thanks to new technologies and in particular to the internet. Customer services in any European country might entail the physical presence of local engineers but technical assistance and communication might be outsourced to Asian countries. The same could be said of the new 'gig economy' in which the relationship between free enterprise and dependence is often difficult to assess. Online platforms allow labour participation on a flexible basis but at the same time question many of the assumptions concerning workers' rights, health insurance and benefits such as remunerated holidays that had been realised during the age of industrial production.

\section{WHY SUBCONTRACTING ?}

The studies we have collected do not take subcontracting as an aberration of the productive system or a simple way of solving market problems. They see it instead as an intrinsic element of the forms of production or commercial exploitation that they address, whether it be located in China, Malaysia or Europe from the early modern era to the present. Depending on the sectors and types of products, subcontracting meets different requirements: in

\footnotetext{
14 BORIS, 1994; TOFFANin, 2016.

15 Robinson, 2008. See in particular 'Global Economy and Latin America II: Industrial Subcontracting, Transnational Services, Tourism, and the Export of Labor', 102-66.

16 Riello, 2008.
} 
the case of public works (Anne Conchon), construction industry (Manuela Martini), shipyards (David Plouviez) or the production of marketable agricultural products (gambier, palm oil) to be used as industrial raw materials (Éric Guerassimoff), it solves logistics issues and problems via the control of monitoring costs. Regarding the production and distribution of industrial and consumer goods (cloth and clothing, toys, shoes), subcontracting guarantees a certain flexibility in contexts of changing demand (Gilles Guiheux) but also in industrial production and distribution (Carles Brasó). Last but not least, for luxury products it allows the optimization of the coordination of highly skilled crafts such as in clock making, in the past (Liliane Hilaire-Pérez and Helen Clifford) or in the present as in the case of Swiss clock making. ${ }^{17}$

Each article in this special issue shows the complexity of unearthing the mechanisms through which subcontract relations were established. From eighteenth-century Britain and France to nineteenth-century Malaysia, to contemporary China, subcontracting requires a criss-crossing of sources. These include trial proceedings (as for instance in the important documents in the Chancery exhibits in the case of London), accounts of bankrupt firms (for instance the dossiers des faillites), records of litigations, labour tribunal referrals and judgments, reports of commissioners and intendants, etc. It is a matter of 'reading between the lines' but as David Plouviez observes, many of the records needed to fully reconstruct a picture of subcontracting as in the case of the French Marine are no longer extant. More rewarding, but equally time consuming, is the analysis of the private contracts signed between the State and the entrepreneurs supplying shipbuilding markets. This is the case of the State's call for tenders and requirements specification as analysed by Anne Conchon. Legal records, proceedings of work arbitration, referrals and legislation (Prud'hommes) as analysed by Manuela Martini are another avenue of enquiry as are the diverse primary sources used by Éric Guerassimoff that include Malay and European archives supplemented by information drawn from Chinese epigraphy and written sources, oral testimonies from descendants, and new findings from French missionary testimonies. Equally revealing are industrial statistics and reports from corporate bodies as those used by Carles Brasó. 
What distinguishes this collection of articles is therefore in the first instance their palette of sources. Yet the articles in this special issue also tell us of the impossibility of bringing the explanation of subcontracting to a single cause. The simple question 'why does subcontracting exist?' thus finds a variety of answers. The essay by Liliane Hilaire-Pérez and Helen Clifford, for instance, sees subcontracting in eighteenth-century metropolitan economies such as London and Paris as a veritable engine of economic growth. Anne Conchon's analysis of production requirements and their infringements in ancient-regime French public works sees in subcontracting a way to cope with manpower shortages and technical issues. Similarly, David Plouviez stresses the need to use subcontracting to overcome logistics problems. Subcontracting allowed the managing of complexity in the pre-industrial world. Key to subcontracting was the access to specific skills often bringing together different skill-sets in the production of complex process. This is the case of the London-based watch and clockmaker James Cox (1723-1800) who said he had access to more than 600 outworkers, while the goldsmiths Parker and Wakelin employed 75 contractors from 1766 to 1770, including artisans in Birmingham and Sheffield, the two rising metalware centres in eighteenth-century England. Anne Conchon asks whether subcontracting depends on the nature of the tasks, their technical difficulty, the size of the sites or the degree of urgency of the work to be done. In a world in which most artisans lacked the capacity to mobilize the technical competence of a skilled workforce, and did not have sufficient capital to successfully complete complex tasks, subcontracting represented a form of 'disintegration' especially of urban production. In striking continuity, Manuela Martini underlines the importance in the nineteenth-century French construction industry of skilled sub-contractors able to monitor workers in a context of shortage in the labour market or lack of the required specialities or crafts. While the theory of the firm underlines how internalisation is key to the achievement of economies of scale through the employment of specialised machinery, subcontracting emphasises instead the role of skills. Yet, as David Plouviez shows, the access to specialised skills was not confined to urban economies or the making of consumer goods: in the 1630s the rising French Navy made use of Dutch carpenters for the construction of specific parts of their vessels, thus producing ships with lower lines, decreasing the size of the rear castles and increasing the artillery.

A second important topic emerging from all contributions is the relationship between subcontracting and division of labour. Adam Smith saw the latter as a source of technical differentiation and skill enhancement. The division of labour was a topic of great concern especially for the guilds dominating traditional trades in pre-industrial Europe. Their training system based 
on apprenticeship entailed the idea of a unity of tasks in the production of distinct typologies of goods (shoes, gold or silverware, etc.) but found it difficult to conceptualize work in different ways, especially in terms of tasks. There was more freedom outside the corporative system. David Plouviez, for instance, observes that by the end of the eighteenth century, the French Navy had long been building its various vessels in twenty-four parts corresponding to a set of predefined tasks. This was also a model used in the production of complex goods such as coaches or clocks made of specialised parts. The account books of the partnership between Benjamin Gray and François Justin Vulliamy in the second half of the eighteenth century shows that half of the forty-three out-workers were located in the neighbourhoods of Soho and Saint-Giles-in-the-Fields in London. Businesses such as Gray and Vulliamy, Liliane Hilaire-Pérez and Helen Clifford observe, required the creation of a new epistemology based on the understanding of work as operative principles, through account book keeping, for the good management of their business. It was argued that trades were being reshaped according to typologies of products - a phenomenon already visible in the proliferation of new guilds both in London and Paris in the second half of the seventeenth century. However, this meant the disappearance of traditional craft identities: the subcontracted artisans were no longer working as craftsmen although they were not yet acting as mechanics. Such a new epistemology required also a new terminology that we see developing over the period from the eighteenth to the twentieth century. This includes expressions, as described by Anne Conchon such as 'adjudication au rabais' (awarding the contract), 'marché à prix faits' (at market prices) or 'marché à l'entreprise' (business market) which recurrently refer to outsourcing as opposed to work done 'par économie' or 'journée du roi'.

A century later, in the construction industry studied by Manuela Martini, there are similar expressions such as working 'à la tâche' (by the task), 'à la pièce' (by the piece), 'au forfait' (fixed price), to indicate the forms of remuneration most often used by the various trades that come together in the production of a building that, unlike earth moving and excavation, were not generally paid by the day.

Third, the multiplicity of definitions of forms of labour remuneration goes hand in hand with the plurality of subcontractor types. The boundaries between self-employed workers and entrepreneurs are blurred. The intermediaries' patterns range from artisans working with a family member to businessmen handling huge financial funds, from subcontractors working only for a single large company and in a semi-subordinate condition, to those diversifying among different companies. In Europe between the end of the nineteenth and the beginning of the twentieth century the entrepreneurial 
nature of subcontracting activities is not clearly defined: the degree of autonomy of the 'tâcheron' with regard to the principal was questioned by the theoreticians and members of courts and arbitration boards in labour courts. The distinction is not easy to define as Manuela Martini shows for construction workers and Éric Guerassimoff for Chinese intermediaries in Malaysia, especially when the subcontractor is a 'manpower entrepreneur', a specific subcontractor profile that emerges not only in theoretical treaties but also as the very real subject of court litigations and thus legal debate. From a macro and industrial perspective Carles Brasó underlines how subcontracting remained integral also in industrial organisation: using the case of woollen production in China between the end of the nineteenth century and World War II, he notices how small and medium-size workshops cohabited with large industrial groups as the latter subcontracted the final stages of production (finishing, but also dyeing, and sewing) and distribution to small workshops. Central to the conceptualisation of subcontracting has also been the new importance given to consumption. Subcontracting has been read as much as a form of organisation of production as a concept and practice in the 'product based economy'. Subcontracting allowed not just the acquisition of skills but, through their constant recombination, also the creation of product variety. It is not by chance that subcontracting has been particularly important in the analysis of the production of coaches, watches and clocks, scientific instruments, furniture, footwear and other consumer goods. This is true for the production of eighteenthcentury 'populuxuries' - combining the appeal of luxuries but made of cheaper materials and sold at low prices - as it is for today's production of Western branded goods (as well as luxury goods) in China and other Asian countries (Gilles Guiheux). Subcontracting impacted not just on commodities and their prices but reshaped the craft economy. Already in 1726 Daniel Defoe made a distinction between those 'who do not actually manufacture the goods they sell', 'those who only make goods for others to sell' and 'those who make the goods they sell though they keep shops'.

Subcontracting does not however exist only in a 'regime of practice'. Since the middle ages it has been the topic of debate and legislative intervention. Unable to control an evolving set of practices, the legal regimes of the time have left us abundant evidence of conflict. We can thus read subcontracting within the realm of the economics of contracts. In eighteenth-century French public works, for instance, subcontracting was formally prohibited or strictly controlled to avoid confusion about legal responsibility and to avoid the risk of increased cost. In practice however, as Anne Conchon observes, subcontracting emerged as a rational response to the restricting nature of the contract competitions for public works in which only approved businesses with a good 
financial capacity were able to compete. In the middle of the nineteenth century, the 'marchandage' prohibition proclaimed by the French Second Republic resulted, particularly in the construction industry, in the punishment of its abuses. Despite the resurgence, particularly at the beginning of the twentieth century, of the action of trade unions against all form of 'marchandage', the legislation of the whole century reiterates the position of the late nineteenthcentury case law. As Manuela Martini demonstrates, only in the late 1930s legislation did the crucial point of the legal sub-contractor status first appear: if the subcontractor is not registered in the commercial records, and is not therefore a legal entrepreneur, the responsibility of the principal contractor towards the sub-contractor's workers is not disengaged.

Another important aspect is the importance of accountancy issues connected to subcontracting. Following Liliane Hilaire-Pérez and Helen Clifford's argument for the creation of a new epistemology of craft, subcontracting was also characterised by the production of a new 'information system' based on financial managerialism and detailed construction plans and specifications so that contractors would have enough information to be able to fulfil their contracts.

In a completely different context, Éric Guerassimoff observes that the system of Chinese intermediaries called Kangchu in Malaysia between the eighteenth and early twentieth centuries mobilized skills including credit and accounting abilities necessary to set up fairly complex businesses. The use of sophisticated information systems characterises subcontracting today. Global production chains and global value chains as conceptualised by Gary Gereffi link different world markets and follow the logic of production in space. As Gilles Guiheux observes, over the past decades, the globalization of value chains initiated by major retailers and brands in the West has been one of the driving forces behind the development of the ready-to-wear industry in China. The productive system is characterized by the interdependence between small units within a given geographical area that is similar to that of a Marshallian district. Yet the logic of today's global subcontracting is less about production and more about the capacity to satisfy quickly and cheaply global consumer markets.

In conclusion, we underline the importance of subcontracting for a social history of work and enterprise. Research until now has focused on the plurality of production worlds, and on the continuous interactions between production and consumption taking into account the variability of demand. We have included the twentieth century and the era of mass production, and touched upon global lengthening of chains of production, and have therefore considered the malleability of this form of production that is integrated into multiple strategies, including those of globalized trade. Whereas in the old regime, as 
Jean-Yves Grenier observed, "the absence of a total recognition of work on the market results from the fact that the pre-industrial production system is characterized less by the purchase of labour than by the external control of the production process operated by the force of exchange and marketing", 18 such an organization of production has retained its importance over centuries and found multiple contemporary expressions. These are the key research attainments. Yet, another theme is emerging: the analysis of the links between subcontracting and domestic and women's work on the one hand, and studies on the importance of micro-workshops in urban areas since modern times on the other, suggest that - socially speaking - this mode of production goes hand in hand with the invisibility of its actors. It is certain that the diversity of socioeconomic status does not allow to the victimisation of subcontractors, who may very well be principals in their turn. Nevertheless, on a structural level, such an organization makes the production process less readable and tends to relegate its actors to an anonymity which they are not subjected to in guilds or in the factory setting, even in the small factory, as shown by the tradition of staff's photographs. Subcontractors belong to the world of networks, intermediaries and production markets. ${ }^{19}$ Their invisibility may even have been a political strategy, as Chandra Mukerji shows for the Canal du Midi, a major public work under Louis XIV marked by the royal handling of the territory through contracting with modest subcontractors instead of famous entrepreneurs, a policy that obscured creative work. ${ }^{20}$ As today deindustrialization is increasing and workers are disappearing or being made invisible in society, the history of subcontracting makes possible a long-term analysis of the multiple forms of the weakening of productive labour. The dynamism of this field of research is in many ways a response to the societal challenges posed by the shrinking of manufacturing in the West.

18 Grenier, 1996, 21.

19 White, 2002.

20 White, 2002. 